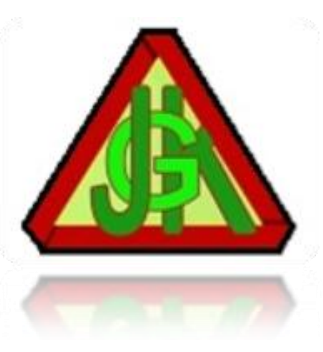

\title{
PENDIDIKAN KESEHATAN DENGAN MEDIA AUDIOVISUAL MEMPENGARUHI PERILAKU PASIEN TB PARU DALAM PENCEGAHAN INFEKSI NOSOKOMIAL COVID-19 DI PUSKESMAS
}

\author{
Ketut Suardana ${ }^{1}$, Komang Trisna Handayani ${ }^{2}$, I Made Mertha ${ }^{3}$, I Wayan Surasta ${ }^{4}$ \\ ${ }^{1,2,3,4}$ Politeknik Kesehatan Kemenkes Denpasar \\ Denpasar, Bali
}

email: $\underline{\text { suarscorpio@gmail.com }}{ }^{1}{ }^{1}$ trisna-handayani28@ gmail.com ${ }^{2}$

mdmertha69@gmail.com ${ }^{3}$, wayansurasta65@gmail.com ${ }^{4}$

\begin{abstract}
ABSTRAK
Pasien dengan kasus tuberkulosis merupakan pasien dengan daya tahantubuh yang lemah dan berpotensi terkena penyakit infeksi nosokomial, sehingga perlu upaya promotif dan preventif selama pasien kontrol pengobatan. Tujuan penelitian ini adalah mengetahui pengaruh pendidikan kesehatan dengan media audiovisual terhadap perilaku pasien TB paru dalam pencegahan infeksi nosokomial COVID19 di Puskesmas Seririt I. Penelitian dilakukan pada bulan April 2021. Jenis penelitian ini adalah Pre-Experimental designs dengan rancangan One-Group Pretest-Posttest. Sampel dipilih menggunakan teknik purposive sampling dengan responden sebanyak 11 orang. Hasil penelitian menunjukkan bahwa nilai rata-rata perilaku pasien TB paru sebelum diberikan pendidikan kesehatan dengan audiovisual, yaitu 57,15 dalam ketegori cukup dan setelah diberikan pendidikan kesehatan dengan nilai rata-rata 85,34 dalam kategori baik. Hasil paired T-test diperoleh $\rho$ - value $=0,000<\alpha(0,05)$, yang berarti ada pengaruh pendidikan kesehatan dengan media audiovisual terhadap perilaku pasien TB paru dalam pencegahan infeksi nosokomial COVID-19. Kepada pemberi layanan kesehatan seperti puskesmas dapat meningkatkan usaha promosi kesehatan utamanya kepada pasien TB paru agar tidak terkena infeksi nosokomial.
\end{abstract}

Kata Kunci: Pendidikan Kesehatan, Media Audiovisual, Perilaku, Infeksi Nosokomial, COVID-19

\footnotetext{
ABSTRACT

Patients with tuberculosis with weak immune systems susceptible to develop nosocomial infections, so that promotive and preventive efforts are needed while the patient is in control of treatment. The aims of this study is to determine the effect of health education with audiovisual media to prevention of COVID-19 nosocomial infection behavior at Patient with pulmonary tuberculosis at Community Health Center Seririt I. This research was conducted in April 2021. The type of this research is Pre-Experimental designs with One-Group PretestPosttest design. The sample was selected using purposive sampling technique
} 
Ketut Suardana, Komang Trisna Handayani, I Made Mertha, I Wayan Surasta.

Desember 2021. 14 (2): 148-156

with 11 respondents. The results showed that the average value of pulmonary tuberculosis patient behavior before being given audiovisual health education, is 57,15 in the sufficient category and after education with audiovisual media 85,34 in the good category. The paired T-test results $\rho$-value $=0.001<\alpha(0.05)$, that mean health education with audiovisual media is effective for changing behavior of pulmonary tuberculosis patients in the prevention of COVID-19 nosocomial infection. Health service providers such as puskesmas can increase health promotion efforts, especially for pulmonary $T B$ patients so that they are not exposed to nosocomial infections.

Keywords: Health Education, Audiovisual Media, Behavior, Nosocomial Infection, COVID-19

\section{PENDAHULUAN}

Pusat Kesehatan Masyarakat (Puskesmas) adalah fasilitas pelayanan kesehatan yang menyelenggarakan upaya kesehatan masyarakat dan upaya kesehatan perseorangan tingkat pertama, dan salah satu tempat pelayanan kesehatan yang rentan terjadi Healthcare Associated Infections (HAIs) atau infeksi

nosokomial. ${ }^{1}$ Pasien dengan kasus tuberkulosis merupakan pasien dengan daya tahan tubuh yang lemah dan berpotensi terkena penyakit infeksinosokomial, hal ini disebabkan karena kondisi pasien yang sangat lemah dan risikodiperparah ketika terjadi penularan infeksi antar pasien. ${ }^{2}$

Pada tahun 2019 sesuai dengan laporan WHO diperkirakan 10 juta orang terserang tuberkulosis (TB) di seluruh dunia dan 1.5 juta berujung kematian. Indonesia menempati peringkat ketiga dengan jumlah penderita TB tertinggi di dunia, di bawah India dan Tiongkok. Berdasarkan data Dinas Kesehatan Provinsi Bali tahun 2019 tercatat kasus penyakit TB Paru tertinggi terjadi di Kota Denpasarsebesar 1.610 kasus. Kabupaten Buleleng menduduki urutan kedua dari Sembilan kabupaten di Provinsi Bali dengan jumlah kasus TB Paru sebanyak 703 kasus pada tahun 2019. ${ }^{3}$ Sejak Maret 2020, WHO menetapkan Corona Virus Disease-19 (COVID-19) sebagai pandemi. WHO menyatakan bahwa pada tahun 2025, maka kasus TB paru akan bertambah menjadi 6,3 juta dan kematian akibat TB paru sebanyak 1,4 juta jiwa. Dalam hal ini Kementerian Kesehatan menekankan pelayanan fasilitas kesehatan untuk pasien TB tidak boleh dihentikan di tengah pandemi COVID-19, karena jika putus obat akan terjadi resisten obat 
Ketut Suardana, Komang Trisna Handayani, I Made Mertha, I Wayan Surasta. Desember 2021. 14 (2): 148-156

danpenularan kepada orang lain. Pasien TB harus melakukan pencegahan seperti yangdisarankan oleh tenaga kesehatan agar terlindungi dari COVID-19 serta tetap melanjutkan pengobatan TB sesuai anjuran. ${ }^{4}$ Mengetahui minimnya media KIE di Puskesmas Seririt I sehingga penyampaian materi khususnya mengenai pencegahan infeksi nosokomial COVID-19 kepada pasien TB Paru masih rendah. Maka dari itu, perlu upaya dalam pencegahan infeksi nosokomial COVID-19 kepada pasien TB Paru selama kontrol pengobatan di Puskesmas, salah satunya dengan media KIE yang menarik seperti media audiovisual dalam bentuk video untuk pendidikan kesehatan.

Penelitian ini bertujuan untuk mengetahui pengaruh pendidikan kesehatan dengan media audiovisual terhadap perilaku pasien TB paru dalam pencegahan infeksi nosokomial COVID-19 di Puskesmas Seririt I.

\section{METODE}

Jenis penelitian ini adalah Quasi-Experimental designs dengan rancangan One-Group Pretest-Posttest. Metode yang digunakan dalam mengumpulkan data perilaku pencegahan pasien TB paru didapatkan dengan menggunakan kuesioner yang diberikan kepada responden. Pengambilan data dimulai dari tanggal 28 Maret-30 April 2021 diperoleh 11 responden. Uji validitas kuesioner didapatkan rentang $\mathrm{r}$ hitung tiap pertanyaan berkisarantara 0,444 sampai dengan 0,710 ( $\mathrm{r}$ tabel = 0,4438). Hasil dari uji reliabilitas kuesioner didapatkan bahwa nilai Cronbach alpha pada 30 item pernyataan adalah sebesar 0,941. Data sebelum dn sesudah diberikan perlakuan dianalisa menggunakan teknik analisis paired t-test.

\section{HASIL DAN PEMBAHASAN}

Penelitian ini dilakukan di Puskesmas Seririt 1, Kabupaten Buleleng, Provinsi Bali. Jumlah responden yang diteliti sebanyak 11 orang. Karakteristik responden disajikan dalam tabel berikut : 
Ketut Suardana, Komang Trisna Handayani, I Made Mertha, I Wayan Surasta. Desember 2021. 14 (2): 148-156

Tabel 1. Distribusi Frekuensi Responden Berdasarkan Jenis Kelamin, usia, lama Pekerjaan, menderita PPOK, riwayat merokok, dan tingkat pendidikan $(\mathrm{n}=11)$

\begin{tabular}{llc}
\hline No $\quad$ Karakteristik Responden & F & \% \\
\hline $1 . \quad$ Jenis Kelamin & 6 & 54,5 \\
a. Laki - Laki & 5 & 45,5 \\
b. Perempuan & & \\
2. Usia & 1 & 9,1 \\
& a. $20-30$ tahun & 36,4 \\
b. $31-40$ tahun & 4 & 27,3 \\
c. $41-50$ tahun & 3 & 18,2 \\
d. $51-60$ tahun & 2 & 9,1 \\
e. $61-70$ tahun & 1 & \\
Pekerjaan & & 54,5 \\
a. Tidak bekerja & 6 & 18,2 \\
b. Petani/Buruh & 2 & 27,3 \\
c. Wiraswasta & 3 & 0 \\
Tingkat Pendidikan & & 0 \\
a. Tidak sekolah & 0 & 18,2 \\
b. SD & 0 & 81,8 \\
c. SMP & 2 & . SMA \\
d. SMAt
\end{tabular}

Berdasarkan tabel di atas terlihat pasien TB Paru di Puskesmas Seririt 1

Buleleng lebih dominan terjadi pada laki-laki dibandingkan perempuan, mayoritas mengenai usia di 31 - 40 tahun $(36,4 \%)$. Responden yang menderita TB Paru lebih banyak pada responden yang tidak bekerja sebanyak 6 orang $(54,5 \%)$, dan paling banyak terjadi pada responden yang berpendidikan SMA.

Untuk menjawab tujuan penelitian maka dilakukan analisis data. Hasil analisis menunjukkan bahwa perilaku pasien TB paru sebelum diberikan pendidikan kesehatan dengan media audiovisual diperoleh hasil sebagai berikut: 
Ketut Suardana, Komang Trisna Handayani, I Made Mertha, I Wayan Surasta. Desember 2021. 14 (2): 148-156

Tabel 2. Tingkat Pengetahuan, Sikap, Tindakan dan perilaku Pasien TB Paru dalam Pencegahan Infeksi Nosokomial Covid-19 di Puskesmas Seririt 1

\begin{tabular}{llccclll}
\hline No & Variabel & N & Mean & Median & Modus & Max - Min & St. Dev \\
\hline 1 & Pengetahuan & & & & & & \\
& Sebelum & 11 & 40,00 & 40 & 40 & $20-70$ & 15,49 \\
& Sesudah & 11 & 90,91 & 100 & 100 & $70-100$ & 11,36 \\
\hline 2 & Sikap & & & & & & \\
& Sebelum & 11 & 65,27 & 64 & 62 & $56-78$ & 6,59 \\
& Sesudah & 11 & 84,36 & 84 & 80 & $80-94$ & 4,37 \\
\hline 3 & Tindakan & & & & & & \\
& Sebelum & 11 & 33,64 & 30 & 30 & $10-50$ & 13,62 \\
& Sesudah & 11 & 84,55 & 90 & 90 & $80-94$ & 12,14 \\
\hline 4 & Perilaku & & & & & & \\
& Sebelum & 11 & 57,15 & 57,10 & 54,30 & $44,3-71,4$ & 7,77 \\
& Sesudah & 11 & 85,34 & 84,3 & 84,30 & $75,7-92,9$ & 5,12 \\
\hline
\end{tabular}

Berdasarkan tabel di atas menunjukkan bahwa dari 11 responden sebelum diberikan pendidikan kesehatan dengan media audiovisual, diperoleh nilai ratarata pengetahuan responden sebesar 40,00; sikap 65,27; tindakan 33,64. Sedangkan setelah diberikan pendidikan kesehatan dengan media audiovisual, didapatkan nilai rata-rata pengetahuan 90,91; sikap 84,36; dan tindakan 84,55.

Untuk mengetahui perbedaan perilaku sebelum dan sesudah pemberian edukasi maka dilakukan uji beda dengan hasil sebagai berikut:

Tabel 3. Perbedaan Tingkat Pengetahuan, Sikap,Tindakan dan Perilaku Pasien TB Paru dalam Pencegahan Infeksi Nosokomial Covid-19 di Puskesmas Seririt 1

\begin{tabular}{lrrrrr}
\hline \multicolumn{1}{c}{ Variabel } & N & Mean & SD & $\begin{array}{c}\text { Selisih } \\
\text { Mean }\end{array}$ & $\rho$-value \\
\hline $\begin{array}{l}\text { Tingkat Pengetahuan } \\
\text { Sebelum }\end{array}$ & 11 & 40,00 & 15,49 & 50,90 & 0,000 \\
Setelah & & 90,91 & 11,36 & & \\
\hline $\begin{array}{l}\text { Sikap } \\
\text { Sebelum }\end{array}$ & 11 & 65,27 & 6,59 & 19,09 & 0,000 \\
Setelah & & 83,36 & 4,37 & & 0,000 \\
\hline $\begin{array}{l}\text { Tindakan } \\
\text { Sebelum }\end{array}$ & 11 & 33,64 & 13,62 & 50,90 & \\
Setelah & & 84,55 & 12,14 & & 0,000 \\
\hline $\begin{array}{l}\text { Perilaku Pencegahan } \\
\text { Sebelum }\end{array}$ & 11 & 57,15 & 7,76 & 28,19 & \\
Setelah & & 85,34 & 5,12 & & \\
\hline
\end{tabular}


Ketut Suardana, Komang Trisna Handayani, I Made Mertha, I Wayan Surasta. Desember 2021. 14 (2): 148-156

Nilai rata-rata pre-test sebesar 57,15 yang termasuk dalam kategori cukup. Hal ini membuktikan bahwa perilaku pasien TB paru belum mencapai maksimal, sehingga kesadaran untuk berperilaku mencegah infeksi nosokomial COVID-19 perlu ditingkatkan pada pasien TB paru yang berobat di Puskesmas Seririt I. Setelah diberikan pendidikan kesehatan dengan media audiovisual terjadi peningkatan perilaku pasien TB paru dengan hasil rata-rata 85,34 yang termasuk dalam kategori baik. Hal ini menunjukkan bahwa responden sudah ada kemajuan berperilaku untuk mencegah infeksi nosokomial COVID-19. Pemberian pendidikan kesehatan dengan cara memberikan tayangan video akan lebih mudah diterima dan diingat oleh pasien karena melibatkan banyak indera, yaitu indera penglihatan dan pendengaran. Sehingga hal yang ditayangkan pada video dapat dilihat maupun didengar secara bersamaan. Hasil analisa dengan uji statistik paired T-test, didapatkan bahwa nilai $\rho$-value pada Sig. (2-tailed), yaitu 0,000 $<\alpha(0,05)$ hal ini berarti hipotesa penelitian diterima yang menunjukkan bahwa ada pengaruh signifikan atau bermakna pendidikan kesehatan dengan media audiovisual terhadap perilaku pasien TB paru dalam pencegahan infeksi nosokomial COVID-19 di Puskesmas Seririt I. Mengacu pada pengukuran tingkat pengetahuan, sikap dan tindakan dengan kategori oleh Arikunto (2017), hasil tersebut termasuk dalam kategori tingkat pengetahuan kurang, sikap dengan kategori cukup dan pada tindakan termasuk kategori kurang. Berdasarkan hasil ketiga domain perilaku, didapatkan hasil rekapitulasi perilaku yang merupakan gabungan hasil dari domain pengetahuan, sikap, dan tindakan yang menunjukkan hasil dari perilaku pasien TB paru dalam pencegahan infeksi nosokomial COVID-19 yang hasilnya diperoleh sebelum edukasi diperoleh rata rata cukup dan setelah edukasi menjadi baik. ${ }^{5}$

Perilaku merupakan hasil hubungan antara perangsang (stimulus) dan respon. Perilaku tersebut dibagi lagi dalam tiga domain yaitu kognitif, afektif, dan psikomotor. Kognitif diukur dari pengetahuan, afektif dari sikap psikomotor dan tindakan (keterampilan). Perubahan perilaku dalam diri seseorang dapat terjadi melalui proses belajar, belajar diartikan sebagai proses perubahan perilaku yang didasari oleh perilaku terdahulu. Dalam proses belajar ada tiga unsur pokok yang 
Ketut Suardana, Komang Trisna Handayani, I Made Mertha, I Wayan Surasta. Desember 2021. 14 (2): 148-156

saling berkaitan, yaitu masukan (input), proses, dan keluaran (output). Individu atau masyarakat dapat mengubah perilakunya bila dipahami faktor-faktor yang berpengaruh terhadapberlangsungnya dan berubahnya perilaku tersebut. ${ }^{6}$

Konsep pendidikan kesehatan merupakan proses belajar dari tidak tahu menjadi tahu tentang kesehatan, dari tidak mampu menjadi mampu dalam mengatasi kesehatannya. Hasil yang diharapkan dari kegiatan pendidikan kesehatan adalah perilaku untuk memelihara dan meningkatkan kesehatan. ${ }^{7}$ Menurut Safitri, dkk (2020) dalam penelitiannya mengatakan bahwa metode pendidikan kesehatan dengan video ini selain untuk media hiburan dan media komunikasi juga dapat digunakan sebagai media edukasi yang mudah dipahami masyarakat dari anak-anak hingga orang tua. ${ }^{8}$

Kurangnya pengetahuan dan informasi untuk pasien TB paru dalam pencegahan infeksi nosokomial COVID-19 yang dapat berpengaruh pada pasien itu sendiri maupun orang disekitarnya. Hal tersebut dikarenakan pasien TB paru menderita penyakit yang menular langsung melalui pernapasan dan tidak menutup kemungkinan untuk terpapar dampak pandemi COVID-19 yang juga dapat menular kepada semua orang dan tidak terkecuali pasien TB paru. Sehingga diperlukan upaya untuk mencegah tertularnya COVID- 19 pada pasien TB paru ketika berobat ataupun berkunjung ke pelayanan kesehatan. Pemberian pendidikan dengan media audiovisual diharapkan mampu membantu pasien TB paru dalam memahami hal yang dapat dilakukan untuk mencegah terjadinya infeksi nosokomial COVID-19 melalui informasi yang disampaikan dalam bentuk video.

Hasil penelitian ini sejalan dengan penelitian yang dilakukan oleh Bili, dkk (2019) yang berjudul "Pengaruh Pendidikan Kesehatan dengan Audiovisual Terhadap Perilaku Pencegahan Penularan pada Keluarga dengan Tuberkulosis Paru di Wilayah Kerja Puskesmas Sikumana" menunjukkan bahwa rata-rata perilaku pencegahan penularan Tuberkulosis Paru sebelum diberikan pendidikan kesehatandengan audiovisual pada domain pengetahuan 7,54, domain sikap 31,11 dan domain tindakan 8,64. Sedangkan sesudah diberikan pendidikan kesehatan dengan audiovisual rata-rata perilaku pencegahan penularan Tuberkulosis Paru pada domain pengetahuan 11,18, domain sikap 34,39 dan domain tindakan 10,57. 
Hal ini menunjukkan terjadi peningkatan rata-rata pada ketiga domain perilaku, yaitu pengetahuan, sikap dan tindakan. ${ }^{9}$ Hasil penelitian ini sejalan juga sejalan dengan penelitian yang dilakukan oleh Safitri, dkk (2020) yang berjudul "Edukasi dengan Media Audiovisual berpengaruh terhadap Perilaku Cuci Tangan pada Keluarga Pasien Rawat Inap di Rumah Sakit Kasih Ibu Surakarta" menunjukkan perbedaan perilaku cuci tangan pre-test dan post-test edukasi dengan media audiovisual menghasilkan nilai rata-rata 3,55 dan 6,57 yang berarti terjadi peningkatan perilaku.

Pengetahuan adalah hasil penginderaan manusia, atau hasil tahu seseorang terhadap objek melalui indra yang dimilikinya. Sebagian besar pengetahuan seseorang diperoleh melalui indra pendengaran dan indra penglihatan. ${ }^{7}$ Menurut Bili, dkk (2019) dalam penelitiannya mengatakan bahwa kelebihan dari media audiovisual, yaitu memiliki pengaruh tiga kali lebih besar untuk meningkatkan pengetahuan, sikap dan tindakan dalam pencegahan penularan Tuberkulosis Paru. $^{9}$

\section{SIMPULAN}

Berdasarkan hasil penelitian pada 11 responden sebelum diberikan pendidikan kesehatan dengan media audiovisual, diperoleh nilai rata-rata pengetahuan responden sebesar 40,00; sikap 65,27; tindakan 33,64 . Sedangkan setelah diberikan pendidikan kesehatan dengan media audiovisual, didapatkan nilai rata-rata pengetahuan 90,91; sikap 84,36; dan tindakan 84,55. Ada pengaruh signifikan atau bermakna pendidikan kesehatan dengan media ausiovisual terhadap perilaku pasien TB paru dalam pencegahan infeksi nosokomial COVID-19 di Puskesmas Seririt I tahun 2021 dengan nilai $\rho-$ value $=0,001$. Hasil penelitian ini diharapkan dapat menjadi acuan ataupun referensi bagipeneliti selanjutnya dalam melakukan penelitian serupa mengenai pengaruh pendidikan kesehatan dengan media audiovisual dengan menggunakan variabel dan metode yang berbeda serta media yang lebih menarik. Hasil penelitian ini juga diharapkan tenaga kesehatan dapat meningkatkan pemberian pendidikan kesehatan mengenai pencegahan infeksi nosokomial COVID-19 kepada pasien TB paru dengan menggunakan media informasi yang menarik dan diberikan secara periodik. 
Ketut Suardana, Komang Trisna Handayani, I Made Mertha, I Wayan Surasta.

Desember 2021. 14 (2): 148-156

\section{UCAPAN TERIMAKASIH}

Peneliti mengucapkan terimakasih kepada Kepala Puskesmas Seririt 1 beserta staff yang telah memberikan izin dan membantu dalam melakukan penelitian ini. Terima Kasi Juga disampaikan Kepada Direktur Poltekkes Kemenkes Denpasar dan Komisi Etik yang telah memberi rekomendasi sehingga penelitian dapat dilaksanakan.

\section{ETHICAL CLEARENCE}

Persetujuan etika penelitian ini diperoleh dari komisi etik penelitian Politeknik Kesehatan Kemenkes Denpasar dengan nomor surat LB.02.03/EA/KEPK/0227/2021

\section{DAFTAR RUJUKAN}

1. Kemenkes RI (2017) 'Peraturan Menteri Kesehatan Republik Indonesia Nomor 27 Tahun 2017 Tentang Pedoman Pencegahan Dan Pengendalian Infeksi Di Fasilitas Pelayanan Kesehatan', 6, pp. 5-9.

2. Soedarto, S. (2016) Infeksi Nosokomial di Rumah Sakit. 1st edn. Jakarta: Sagung Seto. Available at: https://www.researchgate.net/publication/310293816.

3. Dinas Kesehatan Provinsi Bali (2019) Profil Kesehatan Provinsi Bali Tahun 2019. Denpasar: Denpasar.

4. Kemenkes RI (2020) 'Protokol Tata Laksana Pasien TB Dalam Masa Pandemi COVID-19 Edisi II (30 Maret 2020)'. Available at: http://www.stoptb.org/assets/documents/COVID/Protocol for TB Services During Covid-19 Pandemic_2nd Ed.pdf.

5. Arikunto, S. (2017) Prosedur Penelitian : Suatu Pendekatan Praktik. Jakarta: Rineka Cipta.

6. Kholid, A. (2014) Promosi Kesehatan. Jakarta: Jakarta: Raja Grafindo.

7. Notoatmodjo, S. (2018) Promosi Kesehatan Teori dan Aplikasi. Jakarta: Jakarta: Rineka Cipta.

8. Safitri, W. et al. (2020) 'Edukasi Dengan Media Audiovisual Terhadap Perilaku Cuci Tangan Pada Keluarga Pasien Rawat Inap', Jurnal Kesehatan Kusuma Husada, pp. 183-192. doi: 10.34035/jk.v11i2.446.

9. Bili, S., Telly, M. and Tanaem, N. F. D. (2019) 'Pengaruh Pendidikan Kesehatan Dengan Audio Visual Terhadap Perilaku Pencegahan Penularan Pada Keluarga Dengan Tuberkulosis Paru', Chmk health journal volume 3, nomor 2 april 2019, 3(April). 